8

\section{Post Occupancy}

(

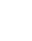

.

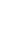

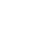

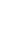

列

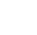

Kenneth T. Sullivan
Associate Professor, Del E. Webb School of Construction, Arizona State University, PO Box 0204,
Tempe, AZ 85287, $\underline{\text { Kenneth.Sullivan@asu.edu 480-965-4273 }}$
Jacob Kashiwagi
Program Manager, Del E. Webb School of Construction, Arizona State University, PO Box 0204,
Tempe, AZ 85287, Jacob.Kashiwagi@asu.edu 480-965-4273

\section{Dhaval R. Gajjar}

Graduate Student, Del E. Webb School of Construction, Arizona State University, PO Box 0204, Tempe, AZ 85287, dgajjar@exchange.asu.edu 480-332-6674

\section{Dean T. Kashiwagi}

Professor, Del E. Webb School of Construction, Arizona State University, PO Box 0204, Tempe, AZ 85287, Dean.Kashiwagi@asu.edu 480-965-4273

\section{Kenneth T. Sullivan}


23 repairing criteria was established after a 6 year mark based on the data that were reported to 24 contractors as vulnerable roofs. Furthermore, the relation between four possible contributing

25 "time of installation" factors - contractor, demographics, season, and difficulty (number of 26 penetrations and size of the roof in square feet) that could affect the quality of the roof was 27 determined. Demographics and difficulty did not affect the quality of the roofs whereas the 28 contractor and the season when the roof was installed did affect the quality of the roofs.

\section{Key Words}

30 Quality, Performance Evaluation, Blister, Roofing, Maintenance 
33 Quality has been a subject of interest in the production and delivery of services for 34 approximately two decades (Lewis, 1993). The term quality is defined differently by different 35 services and there is no consensus on any one specific definition of quality (Wicks and 36 Roethlein, 2009; Sower and Fair, 2005). Reaching a common definition of quality between

37 owners and contractors is critical in order to achieve the desired expected quality since a 38 building's service life is directly impacted by quality (Newton \& Christian 2006; Zbranek, 39 2000). There are multiple researchers that define and study various ways on achieving quality 40 using different quality methods.

41 One such method of construction quality can ultimately be achieved through the setting of 42 specific performance standards and processes (Horowitz, 2001). Quality of the materials used in 43 the construction is also an important element, which can be achieved through planning, 44 prevention, appraisal and specific corrective actions (Stukhart, 1989). The efforts that the 45 contractor and engineers put in to produce a finished product, based on contract plans, 46 specifications and meeting customer satisfaction requirements, can also be defined as quality 47 (Hart 2005; Flynn et. al. 1994; Burati et al. 1991). Newton and Christian (2006) and Garcez et. 48 al. (2013) also suggests that the quality of a building can be influenced in the initial design 49 phase. The total quality management (TQM), supply chain and their partnering methods are 50 currently being used in the construction industry to solve the problem of low or poor quality. 51 However, these methods yield the desired result only with the creation of quality culture for 52 different parties to operate in (Gopal \& Wong, 1998). Vecchi \& Brenna (2009) uses national 53 culture to identify differences in quality management. 
54 Other quality methods such as lean production and six sigma have found success in the 55 manufacturing market, but they have been unable to find a niche in the construction industry, 56 creating ambiguity (Sullivan, 2011; Tam et. al., 2008). ISO 9000, a guideline to establishing a 57 new quality system or altering the existing system to meet the requirements, has been applied in 58 the construction industry throughout past decade as a desirable quality measurement system 59 (Low \& Hennie, 1997). Performance measurement itself has been given a lot of attention in the 60 past fifteen years in terms of research (Bassioni et. al. 2004; Yang et. al., 2010). One suggestion 61 that has been made is that a quality-measurement matrix should be executed for quality 62 performance measurements in the construction industry (Stevens et. al. 1994). The leadership 63 model in the organization is also seen as one of the key successes to achieving quality. Also, 64 leadership in the organization needs to be strong and committed in order to implement a 65 successful quality process (Shiramizu \& Singh, 2007). Kuprenas (2008) has used total project 66 cost (design, management, inspection, testing) to measure the construction quality.

67 Some researchers have suggested measuring quality and implementing quality methods during the post-construction phase. The Post Occupancy Evaluation (POE) method, where a finished 69 product is evaluated to measure the quality for continuous improvement on future products, is 70 currently being implemented in the industry (Wicks and Roethlein, 2009). Also to measure 71 quality, owner satisfaction questionnaires have been distributed after each project to impact 72 future projects positively through corrective behavior modifications (Forbes 2002; Gajjar et. al. 73 2012). Inspections also are crucial in the occupancy stages after the construction has been 74 completed to find the latent defects that were not visible during the inspection in the construction 75 phase (Chong \& Low 2005). Measurement of the effectiveness of Quality Assurance systems are 76 being used to improve quality in the construction industry (Ahmed et. al. 1998). The Key 
77 Performance Indicator (KPI) is another quality measurement method where all stakeholders,

78 including clients, facilitators, and other participants take part in the measurement process as

79 performance indicators (Lin et. al. 2011; Lavy, 2011).

80 The construction industry consists of many different sub-categories like roofing, painting,

81 mechanical, electrical, masonry, thermal and moisture protection, etc. and identification and

82 maintenance of quality in all sub-categories is crucial for a final quality product. Focusing on

83 the roofing sector, there are many types of roofing systems currently in the construction industry

84 and installation of a quality roofing product is essential for smooth functioning of the building.

85 This paper focuses on the one of the roofing sectors in the construction industry known as

86 Sprayed Polyurethane Foam (SPF). SPF-based roof systems are constructed by mixing and

87 spraying a two-component liquid that forms the base of an adhered roof system. The first component of an SPF-based roof system is rigid, closed cell, spray polyurethane foam insulation.

89 The second component, the protective surfacing, typically is a spray applied elastomeric coating, 90 though hand and power rollers can be used (www.nrca.net). SPF roofing has an R-value of six 91 per inch and is used by the owners of the building as a recover system over existing roofs 92 including built-up roof, modified bitumen, concrete, wood, asphalt shingles, clay tile, and metal 93 (Knowles, 2005). The effective service life of an SPF product, as per Dr. Rene Dupuis of the 94 National Roofing Foundation, is up to thirty years.

95 Studies have been conducted to evaluate the long-term weathering effects of performance of SPF 96 roofs to determine energy savings, dynamics of heat transfer and the long-term degradation 97 (Alumbaugh et. al 1984). Studying the causes and effects of SPF roofing defects have revealed that the main reason for these poor results are design, materials, surface anomalies, installation 
99 workmanship and overall maintenance that lead to leaking, blistering, open holes and shortened 100 service life (Bailey \& Bradford 2005).

101 Some of the installation challenges for SPF roofing include cleanup if foam is not sprayed 102 correctly, moisture content and installation errors. SPF roofing needs specialized equipment that 103 includes a high pressure gun that shoots liquid foam which quickly hardens as it is exposed to 104 air. If the liquid foam is sprayed in the cavities between walls and ceilings, it is a challenge to 105 cleanup. Trapping of moisture due to open-cell spray foam when insulating roofs can result in rot 106 and mold problems. During installation, handling spray foam could be a challenge due to 107 expansion of spray insulation as it dries that can cause the walls to buckle and crack (Solomon, 108 2011).

109 Owners are buying SPF roofing products by relying on long-term warranties that have inclusions 110 that protect the manufacturer and has no correlation to the proven documented performance of 111 the capability of the contractors and the product (Kashiwagi 2011). In order to monitor quality 112 and overall performance, regular data collection is crucial (Tam et. al 2008). One such method is 113 visual inspection and condition assessment procedures that provide data to determine roof 114 performance (Bailey \& Bradford 2005; Coffelt et. al. 2010). Evaluating roof coverings using 115 physical inspection and reporting the repair or replacement conditions to the owner have been 116 used for asphalt composition shingles, wood shingles and shakes, and slate and clay tile roofs 117 (Sharara et. al. 2009).

118 Instead of using performance information, the roofing industry uses specifications to ensure 119 optimal quality of the final product which is not a good approach. This paper presents an analysis 120 of the effects on the quality of SPF roofs over time based upon the installing contractor, season 
121 of installation, difficulty (number of penetrations and size of the roof), and local demographics at

122 the buildings' locations by measuring the percentage of blisters on 37 roofs over a three year

123 period of 4, 6, and 7 year increments through visual inspection that can potentially be added to

124 roofing specifications before bidding the job. The cost information (installation and

125 maintenance) for the roofing projects was not well documented and thus was not available to the

126 authors. Cost in relation to quality has unfortunately been omitted from this study.

\section{Methodology}

128 One building owner that has been using SPF roof for approximately 10 years was selected for 129 this specific research. The building owner is a large, urban school district in a high-hail fall 130 region of the United States. A measurement structure was implemented to measure the 131 performance of SPF roofs installed in 2005 and 2006. A quality inspection was conducted three 132 times over a period of 4 year, 6 year and 7 year periods for each roof. In 2011, the repairing 133 criteria were identified based on the 4 year and 6 year measurement.

134 Identifying roofing projects for inspection:

135 The contractors that installed the SPF roofing for a subject building owner are part of a high 136 performance roofing program. The program is established only for SPF roofing contractors by a 137 coating manufacturer that qualifies and disqualifies contractors based on performance 138 measurements using end user satisfaction ratings. The requirements of the program are:

139 1. Have a "good financial standing" and "be licensed" with the manufacturer

1402 2. Roof inspections once every two years of a minimum of 25 roofs by a third-party $141 \quad$ inspector

142 3. Annual submission of newly installed SPF roofs over 5,000 SF 
4. $98 \%$ of roofs being tracked cannot currently leak

5. $98 \%$ of surveyed roofs must have satisfied customers

6. The contractors must attend annual educational presentation.

146 From the annual submission of installed SPF roofs over 5,000 SF, thirty seven urethane coated 147 SPF roofs were identified that were installed in 2005 / 2006 for this research. All the roofs have 148 the same structure and the same system.

\section{Inspection Data Survey:}

150 One of the problems faced by the foam roofing industry is the poor quality of workmanship in 151 SPF roofing (Kashiwagi \& Tisthammer 2002). As mentioned, the common causes of blistering 152 and surface defects are application errors. An inspection data survey was used to measure the 153 percentage of blisters and surface defects of the SPF roofs (Appendix 1).

154 Pre-inspection:

155 Four contractors (Contractor A, Contractor B, Contractor C, and Contractor D) in the high 156 performance roofing program and a client that uses the four contractors were notified prior to 157 conducting the inspections. Three of the contractors agreed to partake in the inspections. The 158 client agreed to help with the efforts in regards to inspections for the fourth contractor. Using 159 mapping software the location of the roofs were identified and optimized for faster and efficient 160 inspections.

\section{Inspection:}

162 The temperature has a direct and crucial effect on blisters. The water that remains in the substrate 163 causes blisters as the system heats in the summer (Jaegermann et. al. 1989). In order to observe 
164 the blistering and surfacing defects for SPF roofs the inspections were held by a certified roof 165 inspector in the summers of 2009, 2011 and 2012 during the month of August. Inspection data 166 survey for each roof was filled out immediately on the roof to reduce human error. The 167 inspections were conducted from 8 AM to 5 PM and lasted for one week for all three year 168 inspection marks.

\section{Post-inspection:}

170 Based on the inspection results in 2011, repairing criteria were established and any SPF roof that 171 met the following criteria must be repaired until the end of the warranty:

172 1. Roofs that have blisters more than $1 \%$ of the total roof area

173 2. Roofs that have open blisters / open cracks

1743 3. Roofs that have a blister size of more than 1 square feet

175 4. Roofs that have current leaks.

176 If a contractor refuses to repair the roofs that met the above criteria, the end user will be 177 dissatisfied affecting the high performance roofing program requirement of 98\% customers 178 satisfied eliminating the contractor from the program.

\section{Analysis}

\section{Repairs:}

181 Based on the criteria, ten roofs and twenty three roofs out of thirty seven roofs were reported as 182 non-performing roofs in 2011 and 2012, respectively (Table 1). No non-performing roofs were 183 reported in 2009. Fig. 1 represents a non-vulnerable roof. After conducting the inspections the 184 respective contractor was notified within one week with the respective non-performing roof. 
185 Every job was given a " $\mathrm{Y}$ " if it meets the repairing criteria and "N" if it does not meet the 186 repairing criteria as shown in Appendix 2. The roofs have to fulfill at least one criterion as a "Y" 187 to be classified as vulnerable.

188 Criteria 1 - Roofs that have blisters on more than $1 \%$ of the total roof area

189 Criteria 2 - Roofs that have open blisters / open cracks (Fig. 2)

190 Criteria 3 - Roofs that have a blister size of more than 1 square foot (Fig. 3)

191 Criteria 4 - Roofs that have current leaks.

192 The contractors were accountable for their work and fixed all the roofs due to the repairing 193 criteria within 90 days of notification.

194 Contractor vs. percent blistered:

195 In order to determine if the contractor awarded the project has an impact on the quality of SPF 196 roofs, the percentage of blisters for each contractor were measured for each year by dividing the 197 total square feet of blisters each year by the total square feet of the roof area inspected (Table 2). 198 The overall percentage of blisters was calculated by dividing the total square feet of blisters for 199 all three years by the total square feet of the roof area inspected for each contractor (Table 3). 200 Based on the data, the contractor vs. percent blistered for each year was plotted as a bar graph 201 (Fig. 4).

202 From the data, Contractor D has the most percentage of blisters while Contractor B has the least 203 percentage of blisters. Contractor D has 136.7\% more percentage of blisters compared to the 204 total average percent blistered of $0.44 \%$. Contractor A has the same percent blistering rate 205 compared to the total average percent blistered, Contractor B has no blisters and Contractor C 
206 has significantly less blisters compared to the total average percent blistered. Considering

207 Contractor D in relation to the other contractors, there is a statistically significant difference with 208 a t-statistic of 2.256, significant at the $95 \%$ level with a p-value of 0.013 .

\section{Season installed vs. percent blistered:}

210 In order to determine if the season the SPF roof was installed has an impact on quality of SPF 211 roofs, the percentage of blisters for each season was determined. The jobs installed in March, 212 April and May were categorized as the Spring season, jobs installed in June, July and August 213 were categorized as the Summer season, jobs installed in September, October and November 214 were categorized as the Fall season and jobs installed in December, January and February were 215 categorized as the Winter season. Overall percent blistered for each season was calculated by 216 dividing the total square feet of blisters for each season by the total roof area for each roof 217 installed for that season (Table 4). Based on the data, a bar graph of season installed vs. overall 218 percent blistered was plotted (Fig. 5).

219 From the data and the graph, the jobs installed in winter season had most percentage of blisters 220 whereas the jobs installed in Spring season had the least percentage of blisters. The winter season 221 had 13.6\% more percent blistered compared to the total average percent blistered of $0.44 \%$ per 222 year. The Spring, Summer and Fall season had 59.1\%, 22.7\% and 52.3\% less percentage of 223 blisters compared to the total average percent blistered of $0.44 \%$ per year. Considering the 224 Spring and Winter quality levels, there is a statistically significant difference with a t-statistic of 225 1.792, significant at the 95\% level with a p-value of 0.042 .

226 Complexity vs. percent blistered: 
227 The complexity of SPF foam roof is determined based on the roof size (square feet) and the

228 number of penetrations on the roof. Roof penetrations are the various types of vents that allow

229 the movement of gas from the inside of the building to the outside. In order to relate the quality 230 of the SPF roofs to its complexity, the percentage of blisters for each roof were plotted using a 231 scattering plot compared to penetration and square feet of a roof.

232 All the roofs that have penetrations between zero and two hundred and fifty were plotted (Fig. 6).

233 One job had a penetration of eight hundred which was excluded from the data as an outlier.

234 Based on the scatter plot, there is no relationship between penetrations (\#) on the roof to the 235 percentage of blisters on the roof. Furthermore, every job was categorized into five categories 236 based on number of penetrations: 0-50, 51-100, 101-150, 151-200, and 201-250 and the total 237 percentages of blisters for each category were calculated (Table 5). Based on data, a graph of 238 penetration categorizes vs. percent blistered were plotted as shown (Fig. 7).

239 However, roofs that had penetrations between 101 and 150 had the least percentage of blisters 240 compared to other penetration range whereas penetrations between 51 and 100 had the most 241 percentage of blisters. There is no relationship between the complexities of number of 242 penetrations of the roof to the percentage of blisters on the roof.

243 Fig. 8 shows the plot of roof size in square feet vs. the percent blistered. There is no relationship 244 between roof size (SF) and percent of roof blistered.

Demographics (median income) vs. percent blistered:

246 In order to determine if the affluence of the surroundings impact the quality of SPF roofs, every 247 roofing job was assigned a zip code based on the location of the school. Every school has 
248 students enrolled from the nearby areas. The average median income for every zip code was

249 obtained using zip atlas. Using the average income of $\$ 32,895$, eighteen jobs were categorized as

250 above average where the average median income was above $\$ 32,895$ and nineteen jobs were

251 categorized as below average where the average median income was below \$32,895.

252 Table 6 shows the percentage of blisters for each category by year. Based on the data, the

253 inspection year vs. percent blistered was plotted as shown in Fig. 9. The jobs that were "above

254 average" location have relatively less percentage of blisters compared to the "below average"

255 location. However, upon performing a t-test, the overall total deviations of the blisters were

256 statistically insignificant with a p-value of 0.13.

\section{Discussion}

258 In the roofing area of the construction industry, specifications play a major role in achieving the

259 desired project result. Moreover, the roofing industry uses specifications as one of the ways to

260 achieve the desired quality of the roof. Most of the specifications in the roofing industry include

261 the description of quality assurance, delivery, storing and handling of materials, application of

262 the product and cleaning and is directly related to product and installing procedures.

263 After identifying the effects of quality on a SPF foam roof based on conditions other than

264 material and installation, the season the roof should be installed affected the quality of the SPF

265 roofs. Some specifications mention the project environmental conditions necessary for the

266 application of the product, but the exact time of the year that the product needs to be installed is

267 missing. From the data, the months of May to September are optimal for the installation of SPF

268 roofs. Adding this criterion to the SPF roof specification can help improve the quality of the SPF 
269 product due to less moisture in the air, and hence less air trapped in the substrate, resulting in

270 minimal blisters increasing the quality of the SPF roof.

271 The type of contractor selected affects the end result of an SPF roof. The SPF roofing

272 specification does not have guidelines that are needed to award a roofing contractor. The

273 specification should include the requirement of past performance information on the roofing

274 projects for the contractors bidding. This will provide a client with the past history of the

275 contractor to perform quality work.

276 The relationship between the quality of an SPF roof to the demographics of the area the roof is

277 installed was studied in order to determine if the surrounding areas and neighborhood affected

278 the contractors perception on the quality while installing the roof. However, there is no causal

279 relationship between mean income of the surrounding community and performance of a roof.

\section{Conclusion}

281 The contractor selected for the installation of the roof affects the quality of SPF roofs. Contractor

282 D had the most percentage of blisters whereas Contractor B had no blisters. The roofing industry

283 relies heavily on the specifications to achieve the desired quality of the SPF roofing system. In

284 spite of the same specifications, the contractors installing the SPF roof had different percentage

285 of blisters after the installation. The authors conclude that along with the specifications the right

286 selection of the contractors is crucial in order to achieve the desired quality of the SPF roofing.

287 This supports the conclusion of Garcez et. al. (2012) that studied ceramic tile roofs and identified

288 the execution errors and maintenance errors were the reasons for the non-performance of ceramic

289 tile roofs. The execution and the maintenance of the roof is the responsibility of the contractor

290 until the end of the warranty. 
291 The quality of SPF roofs is also affected by the season the roof is installed. The roofs that were 292 installed in the winter season have $13.6 \%$ more percentage of blisters compared to the average 293 percent blistered, whereas roofs installed in summer, fall and spring have a relatively less 294 percentage of blisters. The installation of SPF roofing should not be conducted in the winter 295 season due to the high moisture content in the atmosphere that can lead to potential failure of the 296 roofing system and cause problems after the installation. Summer season is concluded to be 297 optimal for the installation of SPF roofing system.

298 The demographics and the difficulty of the roofs did not affect the quality of the roofs. The 299 locations where the roof was installed in the "below average" category where the average median 300 income was below the overall average income of $\$ 32,895$ had $17.5 \%$ more blisters compared to 301 “above average” category. Therefore, it can be concluded that below average household areas 302 have more percentage of blisters on the roofs compared to above average households, but the 303 overall total deviation is insignificant with a p-value of 0.13 .

304 The complexity of the roof in regards to the roof size in square feet and the number of 305 penetrations had no relationship with the percentage of blisters on the roof. Hence, the 306 complexity of the roof did not affect the quality of the SPF roof.

307 The contractors selected for this research are from the high performance roofing program that is 308 a quality based program that creates accountability among SPF roofing contractors by repairing 309 the roofs until the end of the warranty. The program uses performance measurements using non310 technical visual inspections that help contractors, clients and manufacturers by inspecting the 311 existing surface condition on the roof. The end user is satisfied with the contractor in the 
312 program leading to a "win-win-win” scenario for contractors, clients and manufacturers due to

313 contractors' accountability after inspections.

314

315

316

317

\section{OWNER INFORMATION}

\section{Appendix 1}

User Name

Building Name

Date Installed

Street Address

Point of Contact

City $\quad$ State Zip

Phone

\section{INPSECTION DATA}

Date Inspected

Is the Roof Slope Less Than $1 / 4$ ” ( 1 = Yes / 0 = No $)$

Does the Roof Have More Than 5\% Ponding Water

YES $\square$ NO

Area if Roof has More Than 5\% Ponding Water (SF)

Does the Roof Have Granules/Aggregate/None

Number of Roof Penetrations (\#)

Total Blisters (SF)

Delamination (SF)

Mechanical Damage (SF)

Bird Pecks (SF)

Repairs (SF)

Is the Roof More Than 1\% Deteriorated (Yes / No)

Area if Roof is More Than 1\% Deteriorated (SF)

Coating Type (Acrylic, Urethane, Silicone, etc.)

Is Roof Recoated? Date if recoated

\section{Vulnerable Roof Identification}

Average Blister Size on the Roof (SF)

\section{$\square$ YES $\square$ NO}


Any Blisters Over One Foot? (Yes / No)

Any Open Blisters on the Roof? (Yes / No)

Does Roof Area have Blisters > 1\%? (Yes / No)

\begin{tabular}{ll}
\hline$\square$ YES \\
\hline$\square$ NES \\
\hline$\square$ NO \\
\hline YES & $\square$ NO
\end{tabular}

Other Comments (Blister, Mechanical Damage, etc.):

\begin{tabular}{|c|c|c|c|c|c|c|c|}
\hline Job Name & Contractor & Job Area & $\begin{array}{c}\text { Date } \\
\text { Installed }\end{array}$ & $\begin{array}{c}\text { Criteria } \\
1\end{array}$ & $\begin{array}{c}\text { Criteria } \\
2\end{array}$ & $\begin{array}{c}\text { Criteria } \\
3\end{array}$ & $\begin{array}{c}\text { Criteria } \\
4\end{array}$ \\
\hline High School 11 & Contractor A & 147,500 & $8 / 26 / 2005$ & $\mathrm{~N}$ & $\mathrm{Y}$ & $\mathrm{Y}$ & $\mathrm{N}$ \\
\hline High School 12 & Contractor A & 45,200 & 7/30/2005 & $\mathrm{N}$ & $\mathrm{Y}$ & $\mathrm{Y}$ & $\mathrm{N}$ \\
\hline High School 13 & Contractor A & 12,000 & 10/21/2006 & $\mathrm{N}$ & $\mathrm{Y}$ & $\mathrm{Y}$ & $\mathrm{N}$ \\
\hline High School 14 & Contractor A & 7,900 & $4 / 12 / 2005$ & $\mathrm{~N}$ & $\mathrm{Y}$ & $\mathrm{Y}$ & $\mathrm{N}$ \\
\hline High School 15 & Contractor A & 64,700 & $2 / 18 / 2005$ & $\mathrm{~N}$ & $\mathrm{Y}$ & $\mathrm{Y}$ & $\mathrm{N}$ \\
\hline High School 16 & Contractor A & 23,000 & $7 / 22 / 2005$ & $\mathrm{~N}$ & $\mathrm{~N}$ & Y & $\mathrm{N}$ \\
\hline High School 17 & Contractor A & 72,600 & $7 / 26 / 2005$ & $\mathrm{~N}$ & $\mathrm{Y}$ & $\mathrm{N}$ & $\mathrm{N}$ \\
\hline High School 18 & Contractor A & 74,000 & $8 / 23 / 2005$ & $\mathrm{~N}$ & $\mathrm{Y}$ & $\mathrm{Y}$ & $\mathrm{N}$ \\
\hline High School 19 & Contractor A & 94,100 & $5 / 31 / 2006$ & $\mathrm{~N}$ & $\mathrm{~N}$ & $\mathrm{Y}$ & $\mathrm{N}$ \\
\hline High School 20 & Contractor A & 68,000 & $7 / 26 / 2005$ & $\mathrm{~N}$ & $\mathrm{Y}$ & $\mathrm{Y}$ & $\mathrm{N}$ \\
\hline High School 21 & Contractor C & 35,200 & 2/16/2006 & $\mathrm{N}$ & $\mathrm{N}$ & Y & $\mathrm{N}$ \\
\hline High School 22 & Contractor C & 55,900 & $3 / 28 / 2005$ & $\mathrm{~N}$ & $\mathrm{~N}$ & $\mathrm{Y}$ & $\mathrm{N}$ \\
\hline High School 23 & Contractor D & 55,460 & 6/3/2005 & $\mathrm{N}$ & $\mathrm{Y}$ & Y & $\mathrm{N}$ \\
\hline High School 24 & Contractor D & 6,000 & $12 / 22 / 2005$ & $\mathrm{~N}$ & $\mathrm{Y}$ & $\mathrm{N}$ & $\mathrm{N}$ \\
\hline High School 25 & Contractor D & 1,600 & $12 / 28 / 2005$ & $\mathrm{~N}$ & $\mathrm{~N}$ & $\mathrm{Y}$ & $\mathrm{N}$ \\
\hline
\end{tabular}

Appendix 2

2011 Non-Performing Roofs

\begin{tabular}{llcccccc}
\hline \multirow{2}{*}{ Job Name } & \multirow{2}{*}{ Contractor } & \multirow{2}{*}{ Job Area } & $\begin{array}{c}\text { Date } \\
\text { Installed }\end{array}$ & $\begin{array}{c}\text { Criteria } \\
\mathbf{1}\end{array}$ & $\begin{array}{c}\text { Criteria } \\
\mathbf{2}\end{array}$ & $\begin{array}{c}\text { Criteria } \\
\mathbf{3}\end{array}$ & $\begin{array}{c}\text { Criteria } \\
\mathbf{4}\end{array}$ \\
\hline High School 1 & Contractor A & 45,200 & $7 / 30 / 2005$ & $\mathrm{~N}$ & $\mathrm{Y}$ & $\mathrm{N}$ & $\mathrm{N}$ \\
\hline High School 2 & Contractor A & 85,000 & $8 / 26 / 2005$ & $\mathrm{~N}$ & $\mathrm{Y}$ & $\mathrm{N}$ & $\mathrm{N}$ \\
\hline High School 3 & Contractor A & 23,000 & $7 / 22 / 2005$ & $\mathrm{~N}$ & $\mathrm{Y}$ & $\mathrm{Y}$ & $\mathrm{N}$ \\
\hline High School 4 & Contractor A & 32,600 & $8 / 1 / 2005$ & $\mathrm{~N}$ & $\mathrm{Y}$ & $\mathrm{N}$ & $\mathrm{N}$ \\
\hline High School 5 & Contractor A & 108,000 & $6 / 10 / 2005$ & $\mathrm{~N}$ & $\mathrm{Y}$ & $\mathrm{N}$ & $\mathrm{N}$ \\
\hline High School 6 & Contractor A & 68,000 & $7 / 26 / 2005$ & $\mathrm{~N}$ & $\mathrm{Y}$ & $\mathrm{N}$ & $\mathrm{N}$ \\
\hline High School 7 & Contractor A & 57,300 & $8 / 3 / 2005$ & $\mathrm{~N}$ & $\mathrm{Y}$ & $\mathrm{N}$ & $\mathrm{N}$ \\
\hline High School 8 & Contractor A & 73,000 & $4 / 1 / 2005$ & $\mathrm{~N}$ & $\mathrm{Y}$ & $\mathrm{Y}$ & $\mathrm{N}$ \\
\hline High School 9 & Contractor D & 6,000 & $6 / 3 / 2005$ & $\mathrm{Y}$ & $\mathrm{N}$ & $\mathrm{Y}$ & $\mathrm{N}$ \\
\hline High School 10 & Contractor D & 79,500 & $2 / 3 / 2006$ & $\mathrm{~N}$ & $\mathrm{Y}$ & $\mathrm{N}$ & $\mathrm{N}$ \\
\hline
\end{tabular}

2012 Non-Performing Roofs 
329 Ahmed, A. A., Williams, T., Hibberd, P., \& Gronow, S. (1998). Measuring the effectiveness of 330 quality assurance systems in the construction industry. Property Management, 16(4).

331 Alumbaugh, R. L., \& Humm, E. F. (1984). Experimental Polyurethane Foam Roof Systems. 332 Journal of Cellular Plastics, 257-273.

333 Bailey, D. and Bradford, D. (2005). ”Membrane and Flashing Defects in Low-Slope Roofing: 334 Causes and Effects on Performance.” J. Perform. Constr. Facil., 19(3), 234-243. doi: 335 10.1061/(ASCE)0887-3828(2005)19:3(234).

336 Bassioni, H., Price, A., and Hassan, T. (2004). ”Performance Measurement in Construction.” J. 337 Manage. Eng., 20(2), 42-50. doi: 10.1061/(ASCE)0742-597X(2004)20:2(42).

338 Burati, J. L., Mathews, M. F., and Kalidindi, S. N. (1991). "Quality management in the 339 construction industry.” J. Constr. Eng. Manage.,117(2), 341-359.

340 Chong, W. and Low, S. (2005). ”Assessment of Defects at Construction and Occupancy Stages.” 341 J. Perform. Constr. Facil., 19(4), 283-289. doi: 10.1061/(ASCE)0887-3828(2005)19:4(283).

342 Coffelt, D., Hendrickson, C., and Healey, S. (2010). ”Inspection, Condition Assessment, and 343 Management Decisions for Commercial Roof Systems.” J. Archit. Eng., 16(3), 94-99. doi: 344 10.1061/(ASCE)AE.1943-5568.0000014.

345 Flynn, B. B., Schroeder, R. G., and Sakakibara, S. (1994). “A framework for quality 346 management research and an associated measurement instrument.” J. Oper. Manage., 11(4), 347 339-366. 
348 Forbes, L. H. (2002). Continuous Learning in Construction through Quality-Based Post 349 Occupancy Evaluation. IIE Annual Conference. Proceedings, 1-7.

350 Gajjar, D. R., Kashiwagi, D. T., \& Kashiwagi, J. (2012). Manufacturer's New Approach To Risk. 351 RICS COBRA 2012, 1859-1868.

352 Garcez, N., Lopes, N., De Brito, J., \& Sá, G. (2012). Pathology, diagnosis and repair of pitched 353 roofs with ceramic tiles: Statistical characterisation and lessons learned from inspections. 354 Construction and Building Materials, 36, 807-819.

355 Garcez, N., Lopes, N., De Brito, J., Sá, G., \& Silvestre, J. D. (2013). The influence of design on 356 the service life of pitched roofs' cladding. ASCE Journal of Performance of Constructed $357 \quad$ Facilities.

358 Gopal, K. K., \& Wong, A. (1998). Quality culture in the construction industry. Total Quality 359 Management, 9(4/5), S113-S140.

360 Hart, J. A. (2005). Construction Quality Management System. ASQ World Conference on 361 Quality and Improvement Proceedings, 59, 353-360.

362 Horowitz, D. (2001). Construction Quality. Professional Builder, 65(8), 35.

363 Jaegermann, C., Puterman, M., and Haviv, E. (1989). ”Blistering of Membranes Over 364 Foam-Concrete Roofs.” J. Mater. Civ. Eng., 1(1), 31-45. doi: 10.1061/(ASCE)0899365 1561(1989)1:1(31).

366 Kashiwagi, D. (2011) PIPS / PIRMS: The Best Value Standard. 11th ed. Tempe: KSM.

367 Kashiwagi, D. T. and Tisthammer, T. (2002) Information Based Delivery System for Sprayed 368 Polyurethane Foam on Roofing, Journal of Thermal Envelope \& Building Science, (26), 33-52. 
369 Knowles, M. (2005, September 29). Specifying SPF Roofing Systems. Retrieved April 17, 2013,

370 from http://www.buildings.com/article-

371 details/articleid/2753/title/specifying\%20spf\%20roofing\%20systems.aspx.

372 Kuprenas, J. A., (2008). Influence of Quality on Construction Costs. AACE International 373 Transactions. (e.g. 2), pp.CSC.05.1 - CSC.05.9.

374 Lavy, S. (2011). A Literature Review on Measuring Building Performance by Using Key 375 Performance Indicators. AEI 2011 : Building Integration Solutions, 406-417.

376 Lewis, B. R. (1993). Service Quality Measurement. Business And Economics--Marketing And 377 Purchasing, 11(4), 4-12.

378 Lin, G., Shen, G., Sun, M., and Kelly, J. (2011). ’Identification of Key Performance Indicators 379 for Measuring the Performance of Value Management Studies in Construction.” J. Constr. Eng. 380 Manage., 137(9), 698-706. doi: 10.1061/(ASCE)CO.1943-7862.0000348.

381 Low, S. P., \& Hennie, F. O. (1997). The effective maintenance of quality management systems 382 in the construction industry. The International Journal of Quality\&Reliability Management, 383 14(8), 768-790.

384 Newton, L. and Christian, J. (2006). "Impact of Quality on Building Costs.” J. Infrastruct. Syst., 385 12(4), 199-206. doi: 10.1061/(ASCE)1076-0342(2006)12:4(199).

386 Sharara, L. M., Jordan, J. W., \& Kimble, R. A. (2009). Residential Roofing Evaluation. Forensic 387 Engineering 2009: Pathology of the Built Environment, 184-193.

388 Shiramizu, S., \& Singh, A. (2007). Leadership to Improve Quality within an Organization. 389 Leadership and Management in Engineering, 7, 129-140. 
390 Solomon, J. (2011, July 12). Problems with Spray Foam Insulation | Javic Homes Blog [Web log 391 post]. Retrieved from http://javichomes.wordpress.com/2011/07/12/problems-with-spray-foam392 insulation.

393 Sower, V., and Fair, F. 2005. There is more to quality than continuous improvement: Listening 394 to Plato, The Quality Management Journal, 12(1): 8-20. Spray polyurethane foam-based (SPF) 395 roof systems | NRCA National Roofing Contractors Association. (n.d.). Retrieved April 17, 2013, 396 from http://www.nrca.net/consumer/types/spf.aspx.

397 Stevens, J., Glagola, C., and Ledbetter, W. (1994). "Quality-Measurement Matrix.” J. Manage. 398 Eng., 10(6), 30-35. doi: 10.1061/(ASCE)9742-597X(1994)10:6(30).

399 Stukhart, G. (1989). ”Construction Materials Quality Management.” J. Perform. Constr. Facil., 400 3(2), 100-112. doi: 10.1061/(ASCE)0887-3828(1989)3:2(100).

401 Sullivan, K. (2011). "Quality Management Programs in the Construction Industry: Best Value 402 Compared with Other Methodologies.” J. Manage. Eng., 27(4), 210-219. doi: 403 10.1061/(ASCE)ME.1943-5479.0000054.

404 Tam, V., Le, K., and Le, H. (2008). ”Using Gaussian and Hyperbolic Distributions for Quality 405 Improvement in Construction: Case Study Approach.” J. Constr. Eng. Manage., 134(7), 555406 561. doi: 10.1061/(ASCE)0733-9364(2008)134:7(555).

407 Vecchi, A., \& Brennan, L. (2009). Quality management: a cross-cultural perspective. Cross 408 Cultural Management, 16(2), 149-164.

409 Wicks, A. M., \& Roethlein, C. J. (2009). A Satisfaction-Based Definition of Quality. The 410 Journal of Business and Economic Studies, 15(1), 82-97. 
411 Yang, H., John F.Y. Yeung, Albert P.C. Chan, Y.H. Chiang, \& Daniel W.M. Chan. (2010). A 412 critical review of performance measurement in construction. Journal of Facilities Management, 413 8(4), 269-284. doi: 10.1108/14725961011078981.

414 Zbranek, S. (2000). Quality construction--part 1: Defining quality construction. Professional 415 Builder, 65(8), 77-80. 